\title{
ANALISIS KUALITAS PELAYANAN TELLER TERHADAP KEPUASAN NASABAH BANK RAKYAT INDONESIA CABANG PAJAJARAN BOGOR
}

\author{
Megawati Syahril \\ Dosen Tetap Fakultas Ekonomi \\ Universitas Pakuan \\ Ryan Agustiawan \\ Mahasiswa Fakultas Ekonomi \\ Universitas Pakuan
}

\begin{abstract}
ABSTRAK
Permasalahan yang dihadapi Bank Rakyat Indonesia dalam menjalankan bisnisnya adalah sebagaimana memiliki tata cara pelayanan teller lebih diutamakan dalam rangka meningkatkan mutu pelayanan serta pemupuk dana masyarakat. Kepuasan nasabah akan terwujud jika perusahaan dapat memenuhi harapan, karena hal ini mempengaruhi tingkat loyalitas nasabah dimasa yang akan datang. Dalam upaya mempertahankan nasabah Bank Rakyat Indonesia. Untuk meningkatkan kepuasan nasabah yaitu dengan meningkatkan pelayanan melalui peranan teller dan CSO karena bagian tersebut yang paling sering didatangi oleh nasabah untuk melakukan transaksi. Hasil pengujian dari hasil persentase delapan belas atribut pelayanan yang ada di Bank BRI Cabang Bogor sudah baik. Hasil ratarata tingkat kepuasan terhadap tingkat kinerja dan harapan nasabah Bank Rakyat Indonesia dari Tingkat Kesesuaian 88,07\% < dari 100\% Maka dari hasil perhitungan tersebut dapat dikatakan bahwa pelayanan tealer Bank BRI belum memenuhi kepuasan nasabah. Berdasarkan asil uji Importence Performance Analysis, Atribut pelayanan yang berada di kuadran A dinilai oleh konsumen penting terapi kinerja atribut pelayanan tersebut belum baik, sehingga konsumen kurang puas. Atribut Pelayanan yang berada di kuadran B atribut pelayanan ini di nilai penting dan kinerjanya di nilai bagus sehingga konsumen puas. Atribut Pelayanan yang berada di kuadran $\mathrm{C}$ atribut ini di nilai kurang penting oleh nasabah dan kinerjanya kurang baik sehingga konsumen kurang puas. Atribut pelayanan yang berada di kuadran D atribut pelayanan ini di nilai kurang penting oleh nasabah tetapi kinerjanya cukup baik sehingga di nilai berlebihan oleh nasabah.
\end{abstract}

Kata Kunci: Kualitas pelayanan dan kepuasan pelanggan

\section{Pendahulan}

Dunia perbankan saat ini mengalami perkembangan yang sangat pesat, sehingga menimbulkan persaingan yang ketat. Parsaingan ini tidak dapat dihindari oleh karena itu 
pihak bank harus bisa memberikan pelayanan yang terbaik agar bisa menarik minat masyarakat untuk menjadi nasabah Bank trsebut. Bank sebagi lembaga keuangan dimana salah satu pokoknya memberikan keredit dan jasa, Pada dasarnya bank merupakan tempat penyimpanan uang.

Permasalahan yang dihadapi Bank Rakyat Indonesia dalam menjalankan bisnisnya adalah sebagaimana memiliki tata cara pelayanan teller lebih diutamakan dalam rangka meningkatkan mutu pelayanan serta pemupuk dana masyarakat. Kepuasan nasabah akan terwujud jika perusahaan dapat memenuhi harapan, karena hal ini mempengaruhi tingkat loyalitas nasabah dimasa yang akan datang. Dalam upaya mempertahankan nasabah Bank Rakyat Indonesia. Untuk meningkatkan kepuasan nasabah yaitu dengan meningkatan pelayanan melalui peranan teller dan CSO karena bagian tersebut yang paling sering didatangi oleh nasabah untuk melakukan transaksi.

PT. Bank Rakyat Indonesia (Tbk) Cabang Bogor Pajajaran merupakan salah satu kantor cabang yang ada di Bogor. Berdasarkan perkembangannya nasabah Cabang Bogor Pajajaran.

Tabel 1.1.

Jumlah nasabah di PT BRI Cabang Bogor Pajajaran

\begin{tabular}{|l|r|}
\hline \multirow{2}{*}{\multicolumn{1}{|c|}{ BULAN }} & \multicolumn{2}{c|}{ TAHUN 2013 } \\
\cline { 2 - 2 } FEBUARI & \multicolumn{2}{c|}{ TABUNGAN } \\
\hline MARET & 8150 \\
\hline APRIL & 8550 \\
\hline MEI & 8320 \\
\hline JUNI & 7945 \\
\hline JULI & 8025 \\
\hline AGUSTUS & 8139 \\
\hline SEPTEMBER & 8096 \\
\hline OKTOBER & 8325 \\
\hline NOVEMBER & 8495 \\
\hline DESEMBER & 8231 \\
\hline JUMLAH & 8150 \\
\hline
\end{tabular}

Sumber : (PT BRI BOGOR PAJAJARAN, 2013) 
Kuaslias pelayanan sangat penting dalam dunia perbankkan. Nasabah dalam hal ini akan merasa puas jika mereka mendapatkan pelayanan dengan baik atau sesuai dengan di tunjukan oleh banyaknya nasabah yang makin naik setiap tahunnya tetapi kenyataannya terjadi fluktuasi.

Ada pun tujuan penelitian ini adalah: 1) Untuk mengetahui kualitas Pelayanan Teller Bank BRI Cabang Pajajaran Bogor; 2) Untuk mengetahui Tingkat Kepuasan Nasabah Bank BRI Cabang Pajajaran Bogor; dan 3) Untuk mengetahui Analisis Kualitas Pelayanan Teller Terhadap Kepuasan Nasabah Pada Bank BRI Cabang Pajajaran Bogor.

\section{Metode Penelitian}

Analisis deskriptif bertujuan untuk mendeskripsikan dan memperoleh gambaran secara mendalam dan objektif mengenai penerapan kualitas pelayanan terhadap kepuasan nasabah bank BRI pajajaran cabang Bogor. Tingkat kesesuaian yang bertujuan untuk mengetahui tingkat kesesuaian antara skor tingkat kinerja atau pelaksana dengan skor tingkat kepentingan atau harapan nasabah. Adapun rumus yang digunakan adalah :

$$
\mathrm{Tki}=\frac{X i}{Y i} x 100 \%
$$

Keterangan:

Tki $=$ Tingkat kesesuaian responden

$\mathrm{Xi}=$ Total penilaian kinerja perusahaan

Yi $=$ Total penilaian kepentingan nasabah

1. Diagram kartesius

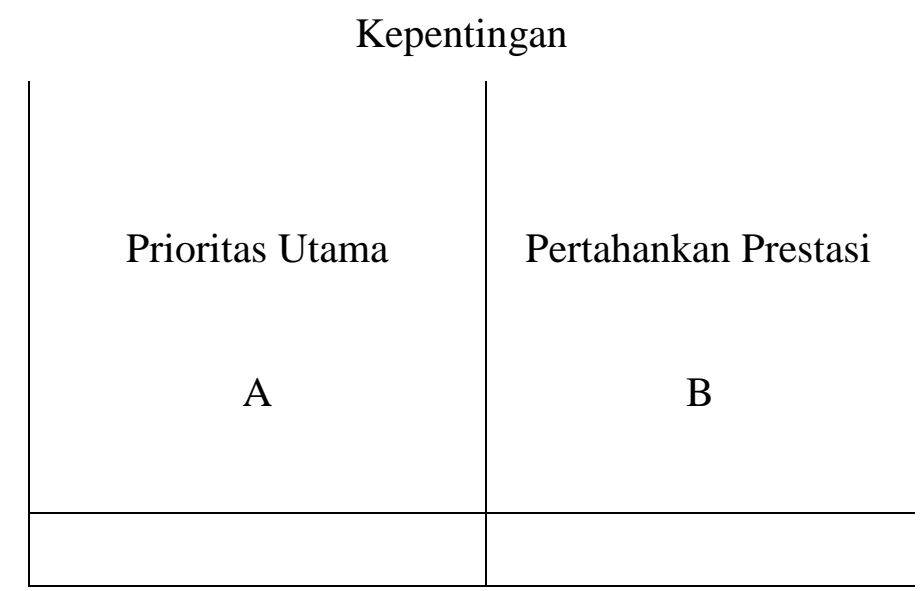




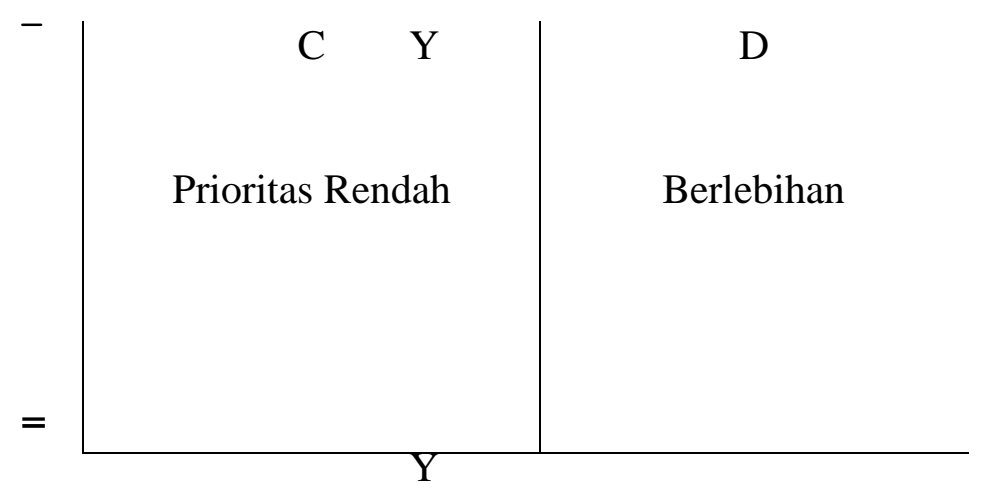

$$
\begin{gathered}
\text { = } \\
\mathrm{X} \\
\text { X Pelaksanaan } \\
\text { (Kinerja/Kepuasan) }
\end{gathered}
$$

Gambar 3.1.

Importance Performance Matrix (Diagram Kartesius)

\section{Keterangan :}

a. Menunjukkan faktor atau atribut yang dianggap mempengaruhi kepuasan pelanggan, termasuk unsur-unsur jasa yang dianggap sangat penting, namun manajemen belum melaksanakannya sesuai dengan keinginan pelanggan, sehingga mengecewakan/tidak puas.

b. Menunjukkan unsur jasa pokok yang telah berhasil dilaksanakan perusahaan, untuk itu wajib dipertahankannya. Dianggap sangat penting dan sangat memuaskan.

c. Menunjukkan beberapa faktor yang kurang penting pengaruhnya bagi pelanggan, pelaksanaannya oleh perusahaan biasa-biasa saja. Dianggap kurang penting dan kurang memuaskan.

Menunjukkan faktor yang mempengaruhi pelanggan kurang penting, akan tetapi pelaksanaannya berlebihan. Dianggap kurang penting tetapi sangat memuaskan. 
Analisis Kualitas Pelayanan Teller terhadap Kepuasan Nasabah Bank Rakyat Indonesia Cabang Pajajaran Bogor

\section{Hasil dan Pembahasan}

\subsection{Analisis Persepsi Tangible}

Tabel 4.1.

Distribusi Frekuensi Jawaban Responden

Penampialn fisik kantor pelayanan

\begin{tabular}{|c|l|c|c|}
\hline Skor & \multicolumn{1}{|c|}{ Jawaban } & Frekuensi & $\%$ \\
\hline 1 & Sangat Tidak Puas & 3 & $0.8 \%$ \\
\hline 2 & Tidak Puas & 7 & $1.8 \%$ \\
\hline 3 & Kurang Puas & 66 & $16.5 \%$ \\
\hline 4 & puas & 302 & $75.5 \%$ \\
\hline 5 & Sangat Puas & 22 & $5.5 \%$ \\
\hline & Total & 400 & $100.0 \%$ \\
\hline
\end{tabular}

Sumber: data olahan hasil kuesioner, 2014.

Tabel 4.2.

Distribusi Frekuensi Jawaban Responden

Fasilitas tempat parkir kendaraan

\begin{tabular}{|c|l|c|c|}
\hline Skor & \multicolumn{1}{|c|}{ Jawaban } & Frekuensi & $\%$ \\
\hline 1 & Sangat Tidak Puas & 3 & $0.8 \%$ \\
\hline 2 & Tidak Puas & 22 & $5.5 \%$ \\
\hline 3 & Kurang Puas & 22 & $5.5 \%$ \\
\hline 4 & puas & 344 & $86.0 \%$ \\
\hline 5 & Sangat Puas & 9 & $2.3 \%$ \\
\hline & Total & 400 & $100.0 \%$ \\
\hline
\end{tabular}

Sumber: data olahan hasil kuesioner, 2012.

Tabel 4.3.

Distribusi Frekuensi Jawaban Responden

Kebersihan kantor pelayanan secara umum

\begin{tabular}{|c|l|c|c|}
\hline Skor & \multicolumn{1}{|c|}{ Jawaban } & Frekuensi & $\%$ \\
\hline 1 & Sangat Tidak Puas & 5 & $1.3 \%$ \\
\hline 2 & Tidak Puas & 30 & $7.5 \%$ \\
\hline 3 & Kurang Puas & 10 & $2.5 \%$ \\
\hline 4 & puas & 215 & $53.8 \%$ \\
\hline 5 & Sangat Puas & 140 & $35.0 \%$ \\
\hline & Total & 400 & $100.0 \%$ \\
\hline
\end{tabular}

Sumber: data olahan hasil kuesioner, 2012. 
Tabel 4.4.

Distribusi Frekuensi Jawaban Responden

Kenyamanan ruang pelayanan

\begin{tabular}{|c|l|c|c|}
\hline Skor & Jawaban & Frekuensi & \% \\
\hline 1 & Sangat Tidak Puas & 2 & $0.5 \%$ \\
\hline 2 & Tidak Puas & 20 & $5.0 \%$ \\
\hline 3 & Kurang Puas & 49 & $12.3 \%$ \\
\hline 4 & puas & 319 & $79.8 \%$ \\
\hline 5 & Sangat Puas & 10 & $2.5 \%$ \\
\hline & Total & 400 & $100.0 \%$ \\
\hline
\end{tabular}

Sumber: data olahan hasil kuesioner, 2012.

Tabel 4.5.

Distribusi Frekuensi Jawaban Responden

Kerapihan dan kebersihan teller dalam berpakaian

\begin{tabular}{|c|l|c|c|}
\hline Skor & Jawaban & Frekuensi & $\%$ \\
\hline 1 & Sangat Tidak Puas & 1 & $0.3 \%$ \\
\hline 2 & Tidak Puas & 25 & $6.3 \%$ \\
\hline 3 & Kurang Puas & 35 & $8.8 \%$ \\
\hline 4 & puas & 140 & $35.0 \%$ \\
\hline 5 & Sangat Puas & 199 & $49.8 \%$ \\
\hline & Total & 400 & $100.0 \%$ \\
\hline
\end{tabular}

(sumber: data olahan hasil kuesioner, 2014).

Tabel 4.6.

Distribusi Frekuensi Jawaban Responden

Kemudaan memperoleh informasi dari teller

\begin{tabular}{|c|l|c|c|}
\hline Skor & \multicolumn{1}{|c|}{ Jawaban } & Frekuensi & $\%$ \\
\hline 1 & Sangat Tidak Puas & 1 & $0.3 \%$ \\
\hline 2 & Tidak Puas & 21 & $5.3 \%$ \\
\hline 3 & Kurang Puas & 33 & $8.3 \%$ \\
\hline 4 & puas & 336 & $84.0 \%$ \\
\hline 5 & Sangat Puas & 9 & $2.3 \%$ \\
\hline & Total & 400 & $100.0 \%$ \\
\hline
\end{tabular}

Sumber: data olahan hasil kuesioner, 2014.

Tabel 4.7.

Distribusi Frekuensi Jawaban Responden

Kemudahan penarikan dana oleh nasahan

melalui teller 
Analisis Kualitas Pelayanan Teller terhadap Kepuasan Nasabah Bank Rakyat Indonesia Cabang Pajajaran Bogor

\begin{tabular}{|c|l|c|c|}
\hline Skor & \multicolumn{1}{|c|}{ Jawaban } & Frekuensi & $\%$ \\
\hline 1 & Sangat Tidak Puas & 3 & $0.8 \%$ \\
\hline 2 & Tidak Puas & 13 & $3.3 \%$ \\
\hline 3 & Kurang Puas & 13 & $3.3 \%$ \\
\hline 4 & puas & 311 & $77.8 \%$ \\
\hline 5 & Sangat Puas & 60 & $15.0 \%$ \\
\hline & Total & 400 & $100.0 \%$ \\
\hline
\end{tabular}

Sumber: data olahan hasil kuesioner, 2014.

Tabel 4.8.

Distribusi Frekuensi Jawaban Responden

Ketelitian teller dalam melakukan setiap transaki

\begin{tabular}{|c|l|c|c|}
\hline Skor & \multicolumn{1}{|c|}{ Jawaban } & Frekuensi & \% \\
\hline 1 & Sangat Tidak Puas & 1 & $0.3 \%$ \\
\hline 2 & Tidak Puas & 21 & $5.3 \%$ \\
\hline 3 & Kurang Puas & 9 & $2.3 \%$ \\
\hline 4 & puas & 215 & $53.8 \%$ \\
\hline 5 & Sangat Puas & 154 & $38.5 \%$ \\
\hline & Total & 400 & $100.0 \%$ \\
\hline
\end{tabular}

Sumber: data olahan hasil kuesioner, 2014.

Tabel 4.9.

Distribusi Frekuensi Jawaban Responden

Kecepatan teller dalam melayani transaksi nasabah

\begin{tabular}{|c|l|c|c|}
\hline Skor & \multicolumn{1}{|c|}{ Jawaban } & Frekuensi & \% \\
\hline 1 & Sangat Tidak Puas & 3 & $0.8 \%$ \\
\hline 2 & Tidak Puas & 20 & $5.0 \%$ \\
\hline 3 & Kurang Puas & 32 & $8.0 \%$ \\
\hline 4 & puas & 237 & $59.3 \%$ \\
\hline 5 & Sangat Puas & 108 & $27.0 \%$ \\
\hline & Total & 400 & $100.0 \%$ \\
\hline
\end{tabular}

Sumber: data olahan hasil kuesioner, 2014.

Tabel 4.10

Distribusi Frekuensi Jawaban Responden

Teller cepat tanggap terhadap masalah yang

di sampaikan nasabah

\begin{tabular}{|c|l|c|c|}
\hline Skor & \multicolumn{1}{|c|}{ Jawaban } & Frekuensi & \% \\
\hline 1 & Sangat Tidak Puas & 8 & $2.0 \%$ \\
\hline 2 & Tidak Puas & 19 & $4.8 \%$ \\
\hline 3 & Kurang Puas & 34 & $8.5 \%$ \\
\hline 4 & puas & 300 & $75.0 \%$ \\
\hline
\end{tabular}




\begin{tabular}{|c|l|c|c|}
\hline 5 & Sangat Puas & 39 & $9.8 \%$ \\
\hline & Total & 400 & $100.0 \%$ \\
\hline
\end{tabular}

Sumber: data olahan hasil kuesioner, 2014.

Tabel 4.11.

Distribusi Frekuensi Jawaban Responden

Jumlah counter teller yang di sediakan untuk melayani nasabah

\begin{tabular}{|c|l|c|c|}
\hline Skor & \multicolumn{1}{|c|}{ Jawaban } & Frekuensi & $\%$ \\
\hline 1 & Sangat Tidak Puas & 4 & $1.0 \%$ \\
\hline 2 & Tidak Puas & 16 & $4.0 \%$ \\
\hline 3 & Kurang Puas & 20 & $5.0 \%$ \\
\hline 4 & puas & 350 & $87.5 \%$ \\
\hline 5 & Sangat Puas & 10 & $2.5 \%$ \\
\hline & Total & 400 & $100.0 \%$ \\
\hline
\end{tabular}

Sumber: data olahan hasil kuesioner, 2014.

Tabel 4.12

Distribusi Frekuensi Jawaban Responden

Keterampilan teller dalam memasukan

data nasabah dengan benar

\begin{tabular}{|c|l|c|c|}
\hline Skor & \multicolumn{1}{|c|}{ Jawaban } & Frekuensi & $\%$ \\
\hline 1 & Sangat Tidak Puas & 1 & $0.3 \%$ \\
\hline 2 & Tidak Puas & 23 & $5.8 \%$ \\
\hline 3 & Kurang Puas & 15 & $3.8 \%$ \\
\hline 4 & puas & 270 & $67.5 \%$ \\
\hline 5 & Sangat Puas & 91 & $22.8 \%$ \\
\hline & Total & 400 & $100.0 \%$ \\
\hline
\end{tabular}

Sumber: data olahan hasil kuesioner, 2014.

Tabel 4.13

Distribusi Frekuensi Jawaban Responden

Keterampilan teller dalam menghitung dana yang masuk atau keluar

\begin{tabular}{|c|l|c|c|}
\hline Skor & \multicolumn{1}{|c|}{ Jawaban } & Frekuensi & \% \\
\hline 1 & Sangat Tidak Puas & 6 & $1.5 \%$ \\
\hline 2 & Tidak Puas & 18 & $4.5 \%$ \\
\hline 3 & Kurang Puas & 78 & $19.5 \%$ \\
\hline 4 & puas & 286 & $71.5 \%$ \\
\hline 5 & Sangat Puas & 12 & $3.0 \%$ \\
\hline & Total & 400 & $100.0 \%$ \\
\hline
\end{tabular}

Sumber: data olahan hasil kuesioner, 2014 
Tabel 4.14

Distribusi Frekuensi Jawaban Responden

Pemberian solusi atas suatu permasalahan

secara terinci sehingga nasabah paham

\begin{tabular}{|c|l|c|c|}
\hline Skor & \multicolumn{1}{|c|}{ Jawaban } & Frekuensi & \% \\
\hline 1 & Sangat Tidak Puas & 4 & $1.0 \%$ \\
\hline 2 & Tidak Puas & 15 & $3.8 \%$ \\
\hline 3 & Kurang Puas & 86 & $21.5 \%$ \\
\hline 4 & puas & 217 & $54.3 \%$ \\
\hline 5 & Sangat Puas & 78 & $19.5 \%$ \\
\hline & Total & 400 & $100.0 \%$ \\
\hline
\end{tabular}

Sumber: data olahan hasil kuesioner, 2014

Tabel 4.15

Distribusi Frekuensi Jawaban Responden

Teller yang kopeten dalam menghadapi nasabah

\begin{tabular}{|c|l|c|c|}
\hline Skor & \multicolumn{1}{|c|}{ Jawaban } & Frekuensi & $\%$ \\
\hline 1 & Sangat Tidak Puas & 3 & $0.8 \%$ \\
\hline 2 & Tidak Puas & 13 & $3.3 \%$ \\
\hline 3 & Kurang Puas & 45 & $11.3 \%$ \\
\hline 4 & puas & 324 & $81.0 \%$ \\
\hline 5 & Sangat Puas & 15 & $3.8 \%$ \\
\hline & Total & 400 & $100.0 \%$ \\
\hline
\end{tabular}

Sumber: data olahan hasil kuesioner, 2014

Tabel 4.16.

Distribusi Frekuensi Jawaban Responden

Keramaha teller terhadap nasabah dalam melaksanakan tugasnya

\begin{tabular}{|c|l|c|c|}
\hline Skor & \multicolumn{1}{|c|}{ Jawaban } & Frekuensi & $\%$ \\
\hline 1 & Sangat Tidak Puas & 3 & $0.8 \%$ \\
\hline 2 & Tidak Puas & 7 & $1.8 \%$ \\
\hline 3 & Kurang Puas & 14 & $3.5 \%$ \\
\hline 4 & puas & 307 & $76.8 \%$ \\
\hline 5 & Sangat Puas & 69 & $17.3 \%$ \\
\hline & Total & 400 & $100.0 \%$ \\
\hline
\end{tabular}

Sumber: Data olahan hasil kuesioner, 2014

Tabel 4.17.

Distribusi Frekuensi Jawaban Responden 
Teller memberikan perhatian kepada indifidu

kepada masing masing nasabah

\begin{tabular}{|c|l|c|c|}
\hline Skor & \multicolumn{1}{|c|}{ Jawaban } & Frekuensi & $\%$ \\
\hline 1 & Sangat Tidak Puas & 5 & $1.3 \%$ \\
\hline 2 & Tidak Puas & 15 & $3.8 \%$ \\
\hline 3 & Kurang Puas & 7 & $1.8 \%$ \\
\hline 4 & puas & 300 & $75.0 \%$ \\
\hline 5 & Sangat Puas & 73 & $18.3 \%$ \\
\hline & Total & 400 & $100.0 \%$ \\
\hline
\end{tabular}

Sumber: data olahan hasil kuesioner, 2014

Tabel 4.18.

Distribusi Frekuensi Jawaban Responden

Kemampuan teller berkomunikasi dengan nasabah

\begin{tabular}{|c|c|c|c|}
\hline Skor & Jawaban & Frekuensi & \% \\
\hline 1 & Sangat Tidak Puas & 0 & $0 \%$ \\
\hline 2 & Tidak Puas & 3 & $0.8 \%$ \\
\hline 3 & Kurang Puas & 46 & $11.5 \%$ \\
\hline 4 & puas & 281 & $70.3 \%$ \\
\hline 5 & Sangat Puas & 70 & $17.5 \%$ \\
\hline & Total & 400 & $100.0 \%$ \\
\hline
\end{tabular}

Sumber: data olahan hasil kuesioner, 2014

Jadi, dari hasil persentase delapan belas atribut pelayanan yang ada di Bank BRI Cabang Bogor, penulis mengambil kesimpulan bahwa dari setiap atribut pelayanan dapat dinyatakan sudah baik karena dari setiap atribut responden menyatakan puas dengan pelayanan yang di berikan teller Bank BRI Cabang Bogor.

\subsection{Analisis Tingkat Kepuasan}

1. Analisis Kepuasan Pelanggan

Atribut-atribut yang dilibatkan dalam penelitian ini, berdasarkan variabelnya masing-masing adalah sebagai berikut:

\section{a. Tangibles}

Penampialn fisik kantor pelayanan, Fasilitas tempat parkir kendaraan, Kebersihan kantor pelayanan secara umum, Kenyamanan ruang pelayanan, Kerapihan dan kebersihan teller dalam berpakaian

\section{b. Reliability}


Kemudaan memperoleh informasi dari teller, Kemudahan penarikan dana oleh nasahan melalui teller, Ketelitian teller dalam melakukan setiap transaki, Kecepatan teller dalam melayani transaksi nasabah

c. Responsiveness

Teller cepat tanggap terhadap masalah yang di sampaikan nasabah, Jumlah counter teller yang di sediakan untuk melayani nasabah

d. Assurance

Keterampilan teller dalam memasukan data nasabah dengan benar, Keterampilan teller dalam menghitung dana yang masuk atau keluar, Pemberian solusi atas suatu permasalahan secara terinci sehingga nasabah paham, Teller yang kopeten dalam menghadapi nasabah

e. Empathy

Keramahan teller terhadap nasabah dalam melaksanakan tugasnya, Teller memberikan perhatian kepada indifidu kepada masing masing nasabah, Kemampuan teller berkomunikasi dengan nasabah

Delapan belas atribut dalam variabel kualitas pelayanan di atas setelah diimplikasikan dalam instrumen penelitian yang menunjukkan hasil tanggapan responden yang merupakan persepsi kepuasan dan harapan mereka. Selanjutnya hasil tanggapan responden yang terkumpul dianalisis menurut analisis tingkat kesesuaian yang telah dijelaskan pada Bab III. Hasil analisis disajikan sebagai berikut. 
Analisis Kualitas Pelayanan Teller terhadap Kepuasan Nasabah Bank Rakyat Indonesia Cabang Pajajaran Bogor

\begin{tabular}{|c|c|c|c|c|c|c|c|c|c|c|c|c|c|c|}
\hline \multirow[t]{2}{*}{ No } & \multirow[t]{2}{*}{ Atribut } & \multicolumn{6}{|c|}{ Tingkat Harapan } & \multicolumn{6}{|c|}{ Tingkat Kinerja } & \multirow{2}{*}{$\begin{array}{c}\text { KESESUAIAN } \\
\text { KP }\end{array}$} \\
\hline & & STP & $\mathrm{TP}$ & KP & $\mathrm{P}$ & SP & TOTAL & STP & TP & KP & $P$ & SP & TOTAL & \\
\hline & Frekuensi & 3 & 7 & 66 & 302 & 22 & & 34 & 113 & 78 & $\begin{array}{r}14 \\
9\end{array}$ & 26 & & \\
\hline 1 & $\begin{array}{l}\text { Penampialn fisik kantor } \\
\text { pelayanan }\end{array}$ & 3 & 14 & 198 & 1208 & 110 & 1533 & 34 & 226 & 234 & $\begin{array}{r}59 \\
6\end{array}$ & 130 & 1220 & $79.58 \%$ \\
\hline & Frekuensi & 3 & 22 & 22 & 344 & 9 & & 13 & 97 & 85 & $\begin{array}{r}16 \\
3\end{array}$ & 42 & & \\
\hline 2 & $\begin{array}{l}\text { Fasilitas tempat parkir } \\
\text { kendaraan }\end{array}$ & 3 & 44 & 66 & 1376 & 45 & 1534 & 13 & 194 & 255 & $\begin{array}{r}65 \\
2\end{array}$ & 210 & 1324 & $86.31 \%$ \\
\hline & Frekuensi & 5 & 30 & 10 & 215 & 140 & & 1 & 37 & 51 & $\begin{array}{r}19 \\
4\end{array}$ & 117 & & \\
\hline 3 & $\begin{array}{l}\text { Kebersihan kantor pelayanan } \\
\text { secara umum }\end{array}$ & 5 & 60 & 30 & 860 & 700 & 1655 & 1 & 74 & 153 & $\begin{array}{r}77 \\
6\end{array}$ & 585 & 1589 & $96.01 \%$ \\
\hline & Frekuensi & 2 & 20 & 49 & 319 & 10 & & 5 & 49 & 115 & $\begin{array}{r}16 \\
2\end{array}$ & 69 & & \\
\hline 4 & Kenyamanan ruang pelayanan & 2 & 40 & 147 & 1276 & 50 & 1515 & 5 & 98 & 345 & $\begin{array}{r}64 \\
8\end{array}$ & 345 & 1441 & $95.12 \%$ \\
\hline & Frekuensi & 1 & 25 & 35 & 140 & 199 & & 4 & 74 & 82 & $\begin{array}{r}18 \\
1\end{array}$ & 59 & & \\
\hline 5 & $\begin{array}{l}\text { Kerapihan dan kebersihan } \\
\text { teller dalam berpakaian }\end{array}$ & 1 & 50 & 105 & 560 & 995 & 1711 & 4 & 148 & 246 & $\begin{array}{r}72 \\
4\end{array}$ & 295 & 1417 & $82.82 \%$ \\
\hline & Frekuensi & 1 & 21 & 33 & 336 & 9 & & 0 & 33 & 68 & $\begin{array}{r}19 \\
1\end{array}$ & 108 & & \\
\hline
\end{tabular}




\begin{tabular}{|c|c|c|c|c|c|c|c|c|c|c|c|c|c|c|}
\hline 6 & $\begin{array}{l}\text { Kemudaan memperoleh } \\
\text { informasi dari teller }\end{array}$ & 1 & 42 & 99 & 1344 & 45 & 1531 & 0 & 66 & 204 & $\begin{array}{r}76 \\
4\end{array}$ & 540 & 1574 & $102.81 \%$ \\
\hline \multicolumn{2}{|r|}{ Frekuensi } & 3 & 13 & 13 & 311 & 60 & & 12 & 62 & 87 & $\begin{array}{r}21 \\
5\end{array}$ & 24 & & \\
\hline 7 & $\begin{array}{l}\text { Kemudahan penarikan dana } \\
\text { oleh nasahan melalui teller }\end{array}$ & 3 & 26 & 39 & 1244 & 300 & 1612 & 12 & 124 & 261 & $\begin{array}{r}86 \\
0\end{array}$ & 120 & 1377 & $85.42 \%$ \\
\hline \multicolumn{2}{|r|}{ Frekuensi } & 1 & 21 & 9 & 215 & 154 & & 25 & 56 & 108 & $\begin{array}{r}18 \\
7\end{array}$ & 24 & & \\
\hline 8 & $\begin{array}{l}\text { Ketelitian teller dalam } \\
\text { melakukan setiap transaki }\end{array}$ & 1 & 42 & 27 & 860 & 770 & 1700 & 25 & 112 & 324 & $\begin{array}{r}74 \\
8\end{array}$ & 120 & 1329 & $78.18 \%$ \\
\hline \multicolumn{2}{|r|}{ Frekuensi } & 3 & 20 & 32 & 237 & 108 & & 18 & 87 & 112 & $\begin{array}{r}16 \\
4\end{array}$ & 19 & & \\
\hline 9 & $\begin{array}{l}\text { Kecepatan teller dalam } \\
\text { melayani transaksi nasabah }\end{array}$ & 3 & 40 & 96 & 948 & 540 & 1627 & 18 & 174 & 336 & $\begin{array}{r}65 \\
6\end{array}$ & 95 & 1279 & $78.61 \%$ \\
\hline \multicolumn{2}{|r|}{ Frekuensi } & 8 & 19 & 34 & 300 & 39 & & 16 & 37 & 89 & $\begin{array}{r}22 \\
4\end{array}$ & 34 & & \\
\hline 10 & $\begin{array}{l}\text { Teller cepat tanggap terhadap } \\
\text { masalah yang di sampaikan } \\
\text { nasabah }\end{array}$ & 8 & 38 & 102 & 1200 & 195 & 1543 & 16 & 74 & 267 & $\begin{array}{r}89 \\
6\end{array}$ & 170 & 1423 & $92.22 \%$ \\
\hline \multicolumn{2}{|r|}{ Frekuensi } & 4 & 16 & 20 & 350 & 10 & & 17 & 110 & 70 & $\begin{array}{r}16 \\
9\end{array}$ & 34 & & \\
\hline 11 & $\begin{array}{l}\text { Jumlah counter teller yang di } \\
\text { sediakan untuk melayani }\end{array}$ & 4 & 32 & 60 & 1400 & 50 & 1546 & 17 & 220 & 210 & $\begin{array}{r}67 \\
6\end{array}$ & 170 & 1293 & $83.64 \%$ \\
\hline
\end{tabular}

Jurnal Ilmiah Manajemen dan Akuntansi Fakultas Ekonomi (JIMAFE)

Volume Semester II 2014 


\begin{tabular}{|c|c|c|c|c|c|c|c|c|c|c|c|c|c|c|}
\hline & \multicolumn{14}{|l|}{ nasabah } \\
\hline \multicolumn{2}{|r|}{ Frekuensi } & & & & & & & & & & 20 & & & \\
\hline 12 & $\begin{array}{l}\text { Keterampilan teller dalam } \\
\text { memasukan data nasabah } \\
\text { dengan benar }\end{array}$ & 1 & 46 & 45 & 1080 & 455 & 1627 & 3 & 202 & 168 & $\begin{array}{r}82 \\
4\end{array}$ & 170 & 1367 & $84.02 \%$ \\
\hline \multicolumn{2}{|r|}{ Frekuensi } & 6 & 18 & 78 & 286 & 12 & & 6 & 92 & 127 & $\begin{array}{r}13 \\
7\end{array}$ & 38 & & \\
\hline 13 & $\begin{array}{l}\text { Keterampilan teller dalam } \\
\text { menghitung dana yang masuk } \\
\text { atau keluar }\end{array}$ & 6 & 36 & 234 & 1144 & 60 & 1480 & 6 & 184 & 381 & $\begin{array}{r}54 \\
8\end{array}$ & 190 & 1309 & $88.45 \%$ \\
\hline \multicolumn{2}{|r|}{ Frekuensi } & 4 & 15 & 86 & 217 & 78 & & 14 & 71 & 139 & $\begin{array}{r}13 \\
5\end{array}$ & 41 & & \\
\hline 14 & $\begin{array}{l}\text { Pemberian solusi atas suatu } \\
\text { permasalahan secara terinci } \\
\text { sehingga nasabah paham }\end{array}$ & 4 & 30 & 258 & 868 & 390 & 1550 & 14 & 142 & 417 & $\begin{array}{r}54 \\
0\end{array}$ & 205 & 1318 & $85.03 \%$ \\
\hline \multicolumn{2}{|r|}{ Frekuensi } & 3 & 13 & 45 & 324 & 15 & & 0 & 39 & 120 & $\begin{array}{r}21 \\
2\end{array}$ & 29 & & \\
\hline 15 & $\begin{array}{l}\text { Teller yang kopeten dalam } \\
\text { menghadapi nasabah }\end{array}$ & 3 & 26 & 135 & 1296 & 75 & 1535 & 0 & 78 & 360 & $\begin{array}{r}84 \\
8\end{array}$ & 145 & 1431 & $93.22 \%$ \\
\hline \multicolumn{2}{|r|}{ Frekuensi } & 3 & 7 & 14 & 307 & 69 & & 7 & 20 & 85 & $\begin{array}{r}20 \\
2\end{array}$ & 86 & & \\
\hline
\end{tabular}




\begin{tabular}{|c|c|c|c|c|c|c|c|c|c|c|c|c|c|c|}
\hline 16 & $\begin{array}{l}\text { Keramaha teller terhadap } \\
\text { nasabah dalam melaksanakan } \\
\text { tugasnya }\end{array}$ & 3 & 14 & 42 & 1228 & 345 & 1632 & 7 & 40 & 255 & $\begin{array}{r}80 \\
8\end{array}$ & 430 & 1540 & $94.36 \%$ \\
\hline & Frekuensi & 5 & 15 & 7 & 300 & 73 & & 7 & 23 & 64 & $\begin{array}{r}20 \\
1\end{array}$ & 105 & & \\
\hline 17 & $\begin{array}{l}\text { Teller memberikan perhatian } \\
\text { kepada indifidu kepada } \\
\text { masing masing nasabah }\end{array}$ & 5 & 30 & 21 & 1200 & 365 & 1621 & 7 & 46 & 192 & $\begin{array}{r}80 \\
4\end{array}$ & 525 & 1574 & $97.10 \%$ \\
\hline & Frekuensi & 0 & 3 & 46 & 281 & 70 & & 18 & 76 & 98 & $\begin{array}{r}14 \\
6\end{array}$ & 62 & & \\
\hline 18 & $\begin{array}{l}\text { Kemampuan teller } \\
\text { berkomunikasi dengan } \\
\text { nasabah }\end{array}$ & 0 & 6 & 138 & 1124 & 350 & 1618 & 18 & 152 & 294 & $\begin{array}{r}58 \\
4\end{array}$ & 310 & 1358 & $83.93 \%$ \\
\hline & TOTAL & $0.0 \%$ & $0.4 \%$ & $8.5 \%$ & $69.5 \%$ & $21.6 \%$ & $100.0 \%$ & $1.3 \%$ & $11.2 \%$ & $21.6 \%$ & $\begin{array}{l}43 . \\
0 \%\end{array}$ & $22.8 \%$ & $100.0 \%$ & \\
\hline
\end{tabular}

Tabel 4.22

Penilaian Kepuasan Pada Tingkat kinerja Dan Tingkat Harapan 
Terhadap variabel persepsi tangible, tingkat kesesuaian tertinggi dicapai untuk atribut Kebersihan kantor pelayanan secara umum $(96,01 \%)$, diikuti atribut Penampialn fisik kantor pelayanan (79.58\%), Fasilitas tempat parkir kendaraan, (86.31\%), Kenyamanan ruang pelayanan, (95.12\%) Kerapihan dan kebersihan teller dalam berpakaian (82.82) Dari Kelima hasil tingkat kesesuaian tersebut masih di bawah 100\% sehingga disimpulkan bahwa untuk pelayanan tangible Bank BRI belum memenuhi kepuasan pelanggan.

Selanjutnya dari atribut variabel reliability, tingkat kesesuaian tertinggi sebesar (102.81\%) Kemudahan memperoleh informasi dari teller (85.42\%), Kemudahan penarikan dana oleh nasahan melalui teller (78.18\%) Ketelitian teller dalam melakukan setiap transaki, (78.61) Kecepatan teller dalam melayani transaksi nasabah. Sedangkan atribut lainnya dengan tingkat kesesuaian di bawah 100\% mengartikan bahwa ketiga atribut tersebut belum memenuhi kepuasan konsumen.

Dari atribut pelayanan responsiveness, semuanya menunjukkan tingkat kesesuaian yang belum memenuhi kepuasan konsumen. Urutan tertinggi adalah atribut Teller cepat tanggap terhadap masalah yang di sampaikan nasabah (92.22), Jumlah counter teller yang di sediakan untuk melayani nasabah (83.64)

Dari atribut Terhadap variabel kualitas pelayanan assurance, tingkat kesesuaian tertinggi dicapai untuk atribut Teller yang kopeten dalam menghadapi nasabah (93.22\%) Keterampilan teller dalam memasukan data nasabah dengan benar (84.02), Keterampilan teller dalam menghitung dana yang masuk atau keluar (88.45) Pemberian solusi atas suatu permasalahan secara terinci sehingga nasabah paham,(85.03) Dengan tingkat kesesuaian di bawah $100 \%$, mengartikan bahwa keempat atribut assurance tersebut belum memenuhi kepuasan konsumen.

Dari dua atribut pelayanan empathy, semuanya menunjukkan tingkat kesesuaian yang belum memenuhi kepuasan konsumen. Urutan tertinggi adalah atribut Teller memberikan perhatian kepada indifidu kepada masing masing nasabah (97.10\%) Keramaha teller terhadap nasabah dalam melaksanakan tugasnya (94.36\%), Kemampuan teller berkomunikasi dengan nasabah $(83.93 \%)$.

Secara umum berdasarkan kelima variabel kualitas pelayanan, nilai tingkat kesesuaian dari seluruh hasil rata- rata tingkat kepuasan terhadp tingkat kinerja dan harapan nasabah Bank Rakyat Indonesia

Tingkat Kesesuaian $=\frac{\text { Tingkat Kinerja }}{\text { Tingkat harapan }} \times 100 \%$

Tingkat Kesesuaian $=\frac{62.91}{71.43} \times 100 \%=88,07 \%$ 
Maka dari hasil perhitungan tersebut dapat dikatakan bahwa pelayanan teller Bank BRI belum memenuhi kepuasan nasabah. Kelima hasil tingkat kesesuaian variabel kualitas pelayanan ini mengindikasikan diperlukannya perbaikan pelayanan Bank BRI guna memenuhi harapan nasabahnya, sehingga pada akhirnya tercapai kepuasan konsumen.

\subsection{Analisis Kualitas Pelayanan terhadap Tingkat Kepuasan Pelanggan}

Dari hasil analisil tingkat kesesuaian, secara keseluruhan kinerja perusahaan belum memenuhi harapan nasabah atau belum memenuhi kepuasan pelanggan, hal ini dapat kita lihat pada tingkat kesesuaian yaitu $88,07 \%<100 \%$.

Berdasakan tabel 4.21 Tingkat kinerja dan Tingkat Harapan rata-rata dapat di buat diagram cartesius sebagai berikut :

Gambar 4.2

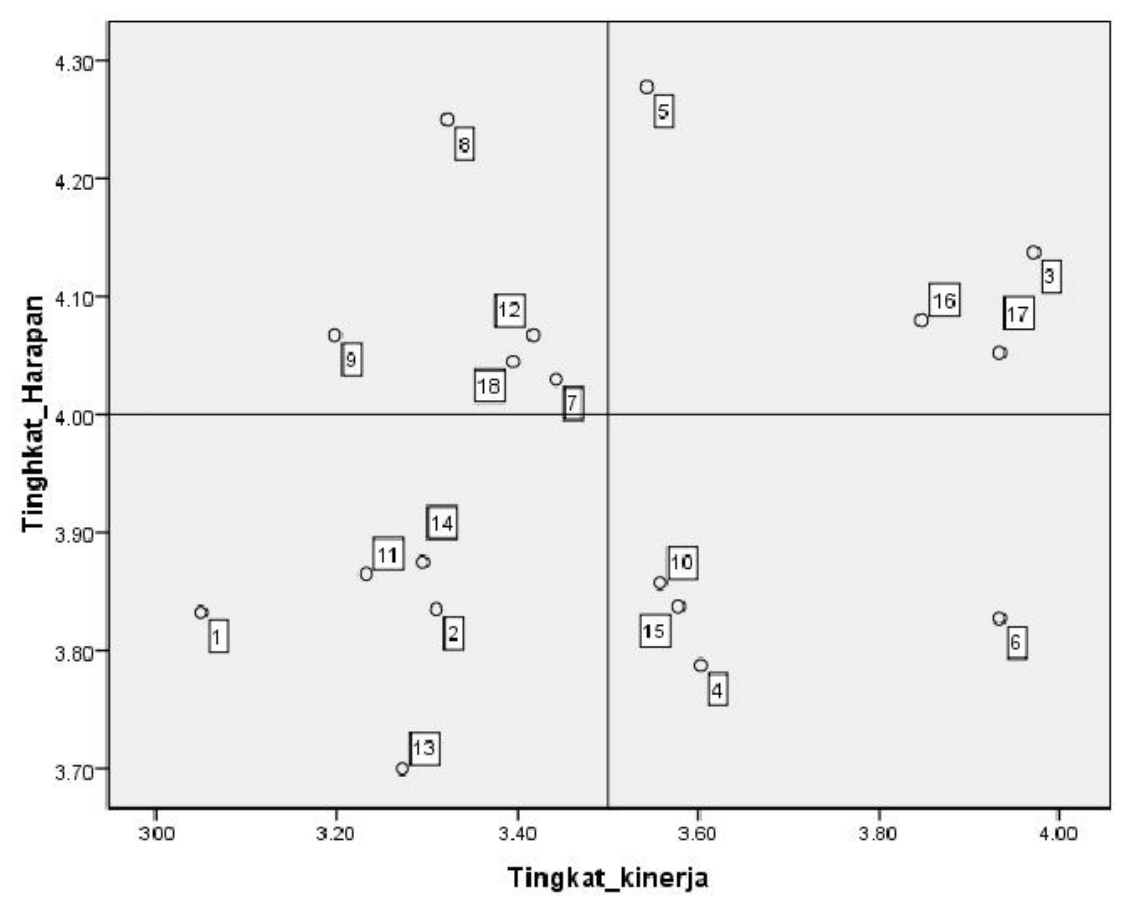


Strategi dibuat berdasarkan posisi masing-masing Indikator dalam kuadran, untuk penjelasannya dapat dilihat sebagai berikut:

\section{A. Kuadran A}

Indikator pelayanan yang dianggap sangat penting pelaksanaannya oleh konsumen tetapi masih menunjukkan kinerja yang belum memenuhi kepuasan konsumen. Sehingga semua indikator yang berada di kuadran ini perlu ditingkatkan, yaitu :

1. Kemudahan penarikan dana oleh nasahan melalui teller

2. Ketelitian teller dalam melakukan setiap transaki

3. Kecepatan teller dalam melayani transaksi nasabah

4. Keterampilan teller dalam memasukan data nasabah dengan benar

5. Kemampuan teller berkomunikasi dengan nasabah

\section{B. Kuadran B}

Indikator yang menunjukkan bahwa unsur pelayanan yang dianggap penting telah dilaksanakan dengan baik oleh perusahaan. Artinya kinerja perusahaan yang tinggi telah memenuhi harapan kepuasan konsumen sehingga semua indikator dalam kuadran ini harus dipertahankan, mencakup

1. Kebersihan kantor pelayanan secara umum

2. Kerapihan dan kebersihan teller dalam berpakaian

3. Keramaha teller terhadap nasabah dalam melaksanakan tugasnya

4. Teller memberikan perhatian kepada indifidu kepada masing masing nasabah

\section{Kuadran C}

Indikator yang terletak pada kuadran ini menunjukkan tingkat kinerja dan harapan yang relatif rendah. Dan ini perlu diperhatikan dan dikelola dengan serius, karena ketidakpuasan pelanggan pada umumnya berawal dari indikator-indikator ini.

1. Penampialn fisik kantor pelayanan

2. Fasilitas tempat parkir kendaraan

3. Jumlah counter teller yang di sediakan untuk melayani nasabah

4. Keterampilan teller dalam menghitung dana yang masuk atau keluar

5. Pemberian solusi atas suatu permasalahan secara terinci sehingga nasabah paham 


\section{Kuadran D}

Kinerja yang menurut pelanggan sangat baik, tetapi Indikator ini memiliki tingkat harapan yang tidak begitu penting. Jadi perlu dipertimbangkan kembali karena dirasakan terlalu berlebihan.

1. Kenyamanan ruang pelayanan

2. Kemudaan memperoleh informasi dari teller

3. Teller cepat tanggap terhadap masalah yang di sampaikan nasabah

4. Teller yang kopeten dalam menghadapi nasabah

Berdasarkan asil uji Importence Performance Analysis, Atribut pelayanan yang berada di kuadran A dinilai oleh konsumen penting terapi kinerja atribut pelayanan tersebut belum baik, sehingga konsume kurang puas. Atribut Pelayanan yang berada di kuadran B atribut pelayanan ini di nilai penting dan kinerjanya di nilai bagus sehingga onsumen puas. Atribut Pelayanan yang berada di kuadran $\mathrm{C}$ atribut ini di nilai kurang penting oleh nasabah dan kinerjanya kurang baik sehinga konsumen kurang puas. Atribut pelayanan yang berada di kuadran D atribut pelayanan ini di nilai kurang penting oleh nasah tetapi kinerjannya cukup baik sehingga di nilai berlebihan oleh nasabah.

\section{Kesimpulan}

1. Dari hasil persentase delapan belas atribut pelayanan yang ada di Bank BRI Cabang Bogor saya mengaambil kesimpulan bahwa dari setiap atribut pelayanan dapat dinyatakan sudah baik karena dari setiap atribut responden menyatakan puas dengan pelayanan yang di berikan teller Bank BRI Cabang bogor

2. Secara umum berdasarkan kelima variabel kualitas pelayanan, nilai tingkat kesesuaian dari seluruh hasil rata- rata tingkat kepuasan terhadap tingkat kinerja dan harapan nasabah Bank Rakyat Indonesia dari Tingkat Kesesuaian 88,07\% < dari 100\% Maka dari hasil perhitungan tersebut dapat dikatakan bahwa pelayanan teller Bank BRI belum memenuhi kepuasan nasabah. Kelima hasil tingkat kesesuaian variabel kualitas pelayanan ini mengindikasikan diperlukannya perbaikan pelayanan Bank BRI guna memenuhi harapan nasabahnya, sehingga pada akhirnya tercapai kepuasan konsumen. 
3. Secara keseluruhan nasabah puas dengan pelayanan Bank BRI Pajajaran Cabang Bogor, Berdasarkan asil uji Importence Performance Analysis, Atribut pelayanan, Kemudahan penarikan dana oleh nasahan melalui teller, Ketelitian teller dalam melakukan setiap transaki, Kecepatan teller dalam melayani transaksi nasabah, Keterampilan teller dalam memasukan data nasabah dengan benar, Kemampuan teller berkomunikasi dengan nasabah dinilai oleh konsumen penting terapi kinerja atribut pelayanan tersebut belum baik, sehingga konsume kurang puas. Atribut yang meliputi Kebersihan kantor pelayanan secara umum, Kerapihan dan kebersihan teller dalam berpakaian, Keramaha teller terhadap nasabah dalam melaksanakan tugasnya, Teller memberikan perhatian kepada indifidu kepada masing masing nasabah atribut pelayanan ini di nilai penting dan kinerjanya di nilai bagus sehingga onsumen puas. Atribut meliputi Penampialn fisik kantor pelayanan, Fasilitas tempat parkir kendaraan , Jumlah counter teller yang di sediakan untuk melayani nasabah, Keterampilan teller dalam menghitung dana yang masuk atau keluar, Pemberian solusi atas suatu permasalahan secara terinci sehingga nasabah paham atribut ini di nilai kurang penting oleh nasabah dan kinerjanya kurang baik sehinga konsumen kurang puas. Atribut yang meliputi Kenyamanan ruang pelayanan, Kemudaan memperoleh informasi dari teller, Teller cepat tanggap terhadap masalah yang di sampaikan nasabah, Teller yang kopeten dalam menghadapi nasabah atribut pelayanan ini di nilai kurang penting oleh nasah tetapi kinerjannya cukup baik sehingga di nilai berlebihan oleh nasabah.

\section{Daftar Pustaka}

Ariani Wahyu. 2009. Manajemen Operasi Jasa. Graha Ilmu, Yoyakarta.

Arman Hakim Nasution, Indung Sudarso, dan Lantip Tri Sunarno. 2006. Manajemen Pemasaran. Erlangga, Jakarta. 
Analisis Kualitas Pelayanan Teller terhadap Kepuasan Nasabah Bank Rakyat Indonesia Cabang Pajajaran Bogor

Buchari Alma. 2002. Manajemen Pemasaran dan Pemasaran Jasa. cetakan ke-5. Alfabeta, Bandung.

Buchari Alma. 2005. Manajemen Pemasarasan dan Pemasaran Jasa. Alfabeta, Bandung.

Byod, Mullins, Walker, and Larecche. 2002. Manajemen Pemasaran. Erlangga, Jakarta.

Eva Z. Yusuf dan Lesley Williams.2007. Manajemen Pemasaran:Studi kasus Indonesia. Alih bahasa: Abdul Rosyid, PPM. Jakarta.

Fajar Laksana. 2008. Manajement Pemasaran Pendekatan Praktis. Graha Ilmu, Yogyakarta.

Fandy Tjiptono. 2006. Strategi Pemasara. Edisi Pertama. Andi Ofset, Yogyakarta.

Fandy Tjiptono. 2008. Strategi pemasaran. Edisi 3.Andi,Yogyakarta.

Nembah F. Hartimbul Ginting. 2011. Management Pemasaran. CV. Yrama Widya, Bandung.

Gaspersz Vincent. 2004. Perencanaan Strategik Untuk Peningkatan Kinerja Sektor Publik.

Gramedia Pustaka Utama, Jakarta.

Henry Simamora. 2007. Manajemen Pemasaran Internasional Jilid 1, Edisi 2. Rinneka Cipta, Jakarta.

Husein Umar. 2005. Riset Pemasaran \& Perilaku Konsumen. PT Gramedia Pustaka Utama, Jakarta.

J. Supranto. 2006. Pengukuran Tingkat Kepuasan Pelanggan. PT. Rineka Cipta, Jakarta.

J. Supranto dan Cimabrisna. 2007. Unsur-unsur Pemasaran. PT. Rineka Cipta, Jakarta.

J. Supranto. 2011. Pengukuran Tingkat Kepuasan Pelanggan. Cetakan 4, PT. Rineka Cipta, Jakarta.

Kotler P. 2004. Manajemen Pemasaran. Edisi Millenium, Jilid 1. PT Indeks, Jakarta. ,and G.Armstrong. 2004. Dasar-dasar Pemasaran. Jilid 2, Edisi Kesembilan, Alih Bahasa Drs. Alexander Sindoro. Indeks, Jakarta. ,and G.Amstrong. (2008). Prinsip-Prinsip Pemasaran. Jilid 1, Edisi 12. Erlangga, Jakarta.

,and K. L. Keller.2008. Manajemen Pemasara. edisi 13, jilid 1. Erlangga, Jakarta.

2009. Manajemen Pemasaran. Edisi 13, Jilid 2. PT. Gelora Aksara Pratama, Jakarta.

, and K. L. Keller. 2009. Manajemen Pemasaran. Edisi 13, Jilid 1. Erlangga, Jakarta.

Mowen J.C. dan M. Minor. 2002. Perilaku Konsumen. Jilid 1, Edisi Ke Lima, Alih Bahasa : Lina Salim. Penerbit Erlangga, Jakarta. 
M. Suyanto. 2004. Manajemen Pemasaran. Yogyakarta

Rambat Lupiyoadi dan A. Hamdani. 2006. Manajemen Pemasaran Jasa. Salemba Empat, Jakarta.

Sofjan Assauri. 2004. Manajement Pemasaran. PT. Raja Grafindo Persada, Jakarta.

Supriadi Setiawan. 2011. Loyalitas Pelanggan Jasa. IPB Press, Bogor.

Titik Nurbiyati dan Machmud Mahfoedz. 2005. Manajemen Pemasaran Kontemporer. Penerbit PT. Indeks, Jakarta. 